\title{
Ankylosis of the hips and knees due to sickle cell disease
}

\section{[version 1; peer review: 2 approved]}

\section{Saad Saleh Abdullah Al Elayan, Abdullah Al Hamdan}

Department of Orthopedics, Prince Sultan Military Medical City, Riyadh, 11612, Saudi Arabia

\author{
V1 First published: 19 Oct 2012, 1:32 \\ https://doi.org/10.12688/f1000research.1-32.v1 \\ Latest published: 19 Oct 2012, 1:32 \\ https://doi.org/10.12688/f1000research.1-32.v1
}

\section{Abstract}

This is a case report of a 29-year-old Saudi male with sickle cell disease (SCD) with severe stiffness of his joints, mainly both knees and hips, secondary to complications of SCD. He was severely crippled: unable to sit, stand or walk, and was bedridden for 8 years when he was presented to us. Radiographs showed fusion of both knees and hips. There was no evidence of active osteomyelitis by Gallium scan. The patient's hemoglobin $\mathrm{S}$ decreased to levels below $30 \%$ by exchange transfusion. Bilateral total hip replacement, as well as unilateral total knee replacement, was carried out to improve his level of function. There is only one reported case of such severe and multiple joint complications in a single patient suffering from SCD.

The increased life expectancy that medical advances have offered to the sickle-cell patients has led to the appearance of sickle-cell-related complications, which were previously only seen rarely. These complications were successfully managed and the patient was able to move and transfer using a wheel chair.

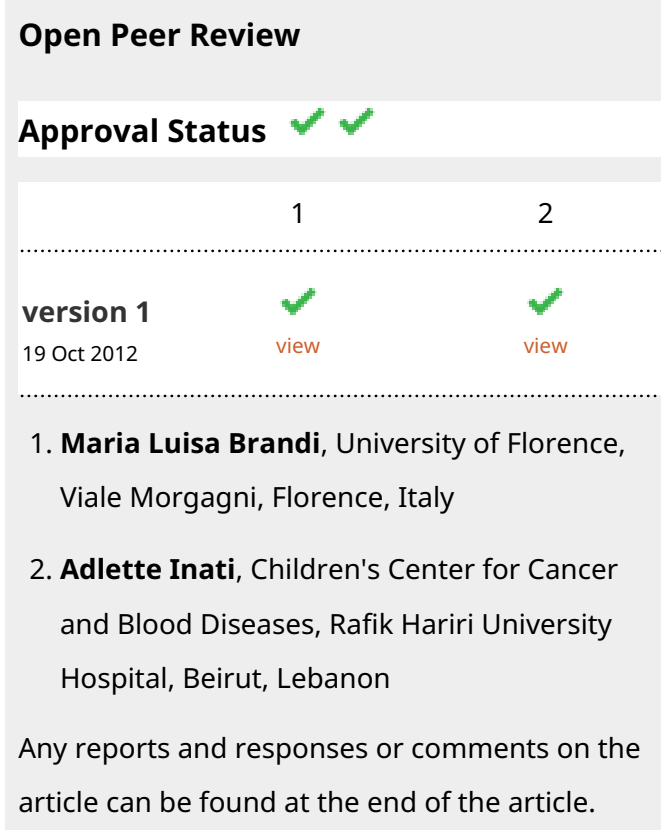

Open Peer Review

Approval Status

1

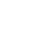

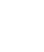

version 1

1. Maria Luisa Brandi, University of Florence, Viale Morgagni, Florence, Italy

Adlette Inati, Children's Center for Cancer and Blood Diseases, Rafik Hariri University Hospital, Beirut, Lebanon article can be found at the end of the article.

Corresponding author: Saad Saleh Abdullah Al Elayan (aysolayan@yahoo.com)

Competing interests: No competing interests were disclosed.

Grant information: The author(s) declared that no grants were involved in supporting this work.

Copyright: @ 2012 Al Elayan SSA and Al Hamdan A. This is an open access article distributed under the terms of the Creative Commons Attribution License, which permits unrestricted use, distribution, and reproduction in any medium, provided the original work is properly cited. Data associated with the article are available under the terms of the Creative Commons Zero "No rights reserved" data waiver (CC0 1.0 Public domain dedication).

How to cite this article: Al Elayan SSA and Al Hamdan A. Ankylosis of the hips and knees due to sickle cell disease [version 1; peer review: 2 approved] F1000Research 2012, 1:32 https://doi.org/10.12688/f1000research.1-32.v1

First published: 19 Oct 2012, 1:32 https://doi.org/10.12688/f1000research.1-32.v1 


\section{Introduction}

Sickle cell disease (SCD) is an autosomal recessive genetic disorder characterized primarily by chronic anemia and periodic episodes of pain, affecting millions throughout the world ${ }^{1}$. SCD patients are at increased risk of bony complications of the disease, such as osteomyelitis, osteonecrosis, osteopenia and ankylosis ${ }^{2}$. SCD is an important public health concern in the Kingdom of Saudi Arabia (KSA), particularly in the Eastern and South West provinces ${ }^{3}$. Painful crises and avascular necrosis of the femoral head are common complications observed in these regions ${ }^{3}$. This case presentation is that of a patient with severe bony complications resulting from his SCD. Total bilateral hip and unilateral knee arthroplasty were performed to correct hip and knee ankylosis secondary to SCD. To our knowledge, total bilateral hip and unilateral knee arthroplasty has not been described previously in the literature except in one case of an African male with a similar presentation ${ }^{4}$.

\section{Case report}

A 29-year-old Saudi male with SCD, was referred from the general surgery service to improve his poor physical condition. He was severely crippled and bed bound for 8 years with severe bilateral knee and hip dysfunction secondary to complications of SCD. Past history included an admission to hospital 8 years before for fever, swelling and severe pain of the right knee. Needle aspiration, as well as irrigation and debridement, was performed and the patient was diagnosed with septic arthritis. Since then he had developed progressive joint stiffness involving the dorsal and lumbar spines as well as the lower extremity.

On physical examination his knee range of motion (ROM) bilaterally was almost nonexistent with the knees held in full extension. His hips ROM was also severely limited, with no ROM. Loss of hip flexion was noted to result in the most severe functional loss with the hips fixed in full extension, adduction of $15^{\circ}$ and $50^{\circ}$ of external rotation. He required a 2-person assist as well as a walker to weight bear however he was unable to mobilize.

Serial radiological studies were done. Radiological investigations demonstrated severe avascular necrosis and ankylosis of the hip (Figure 1) and severe erosion of the articular surfaces of the knees as well as ankylosis (Figure 2). Computed tomography (CT) scan of the hips and knees showed similar findings as that of the X-rays. Shoulders and spine X-ray were done for further assessment. Gallium bone scan demonstrated no evidence of active osteomyelitis. Our patient had a proper preoperative evaluation and blood transfusion to prevent adverse outcomes and sickle cell complications postoperatively ${ }^{5}$. We took him to surgery for bilateral cementless total hip replacement (THR) in one session.

The patient was operated on with an aim to provide movement at the hips and knees and to recover his ability to sit, stand, transfer, balance and improves personal hygiene. Bilateral THR was done successfully (Figure 3). The procedures were performed utilizing the Harding lateral approach. Particular attention was paid to padding bony prominences and skin care in view of his poor skin condition. Intraoperatively, the bone was noted to be very fragile. The patient was kept in the intensive care unit for two days post operatively for observation and pain control. Post bilateral THR, the

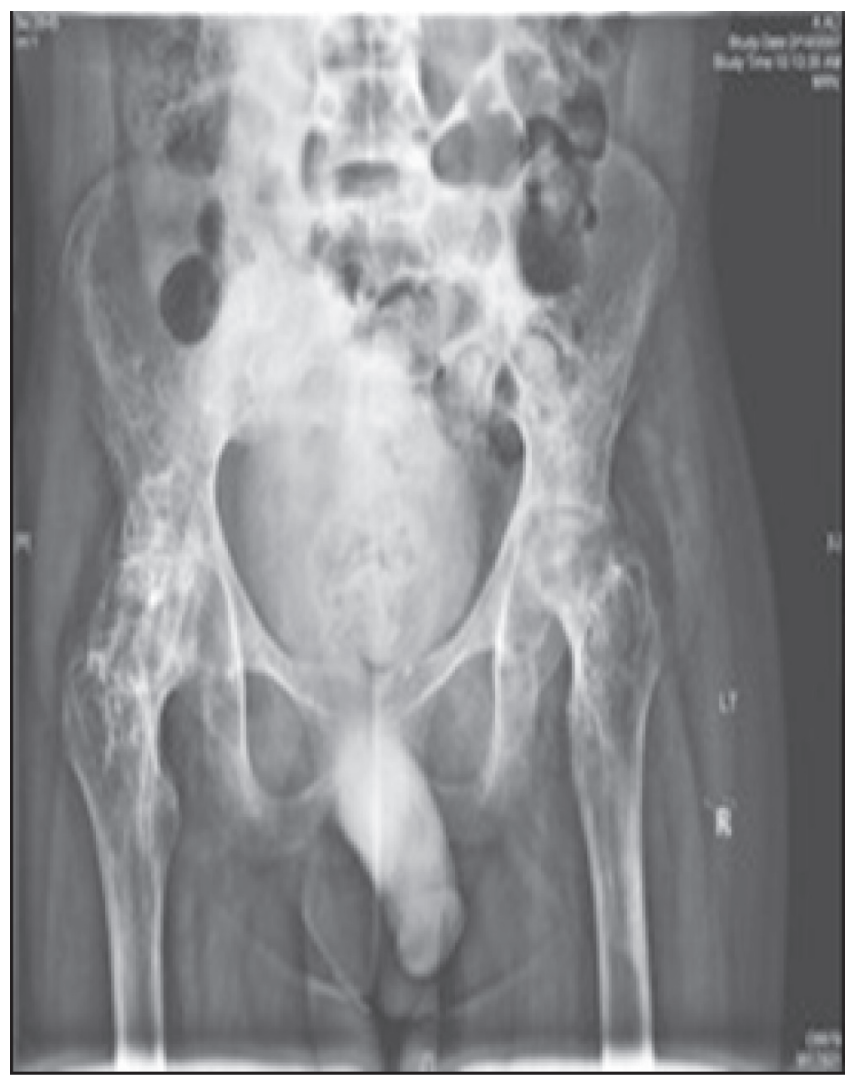

Figure 1. AP Hips x-rays showed severe avascular necrosis and ankylosis.
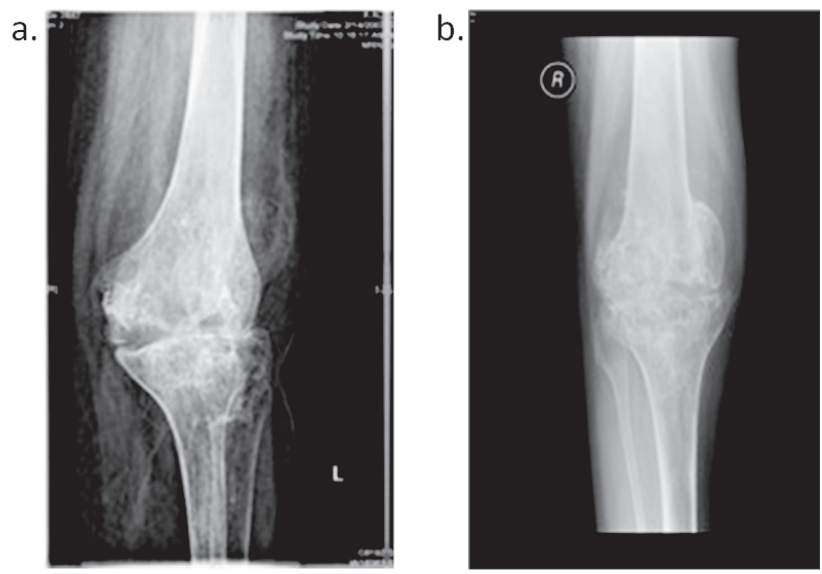

Figure 2. AP left \& right knee x-ray shows erosion and ankylosis.

patient had marked improvement of hip flexion bilaterally permitting easy functional sitting. Post surgery physiotherapy resulted in great improvement in his general physical activity.

Left total knee replacement (TKR) was performed one month after the THR (Figure 4). Intraoperatively, the bone quality was noted to be severely deficient. The quadriceps muscle was adherent to the 


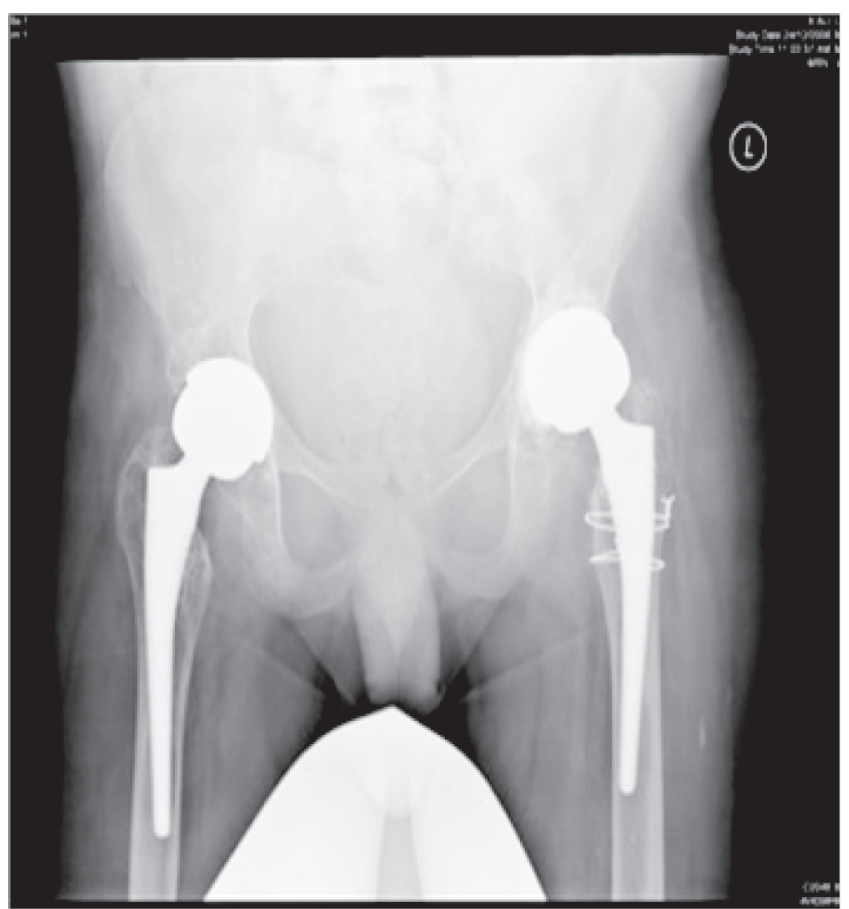

Figure 3. AP pelvis x-ray post bilateral THR.

a.

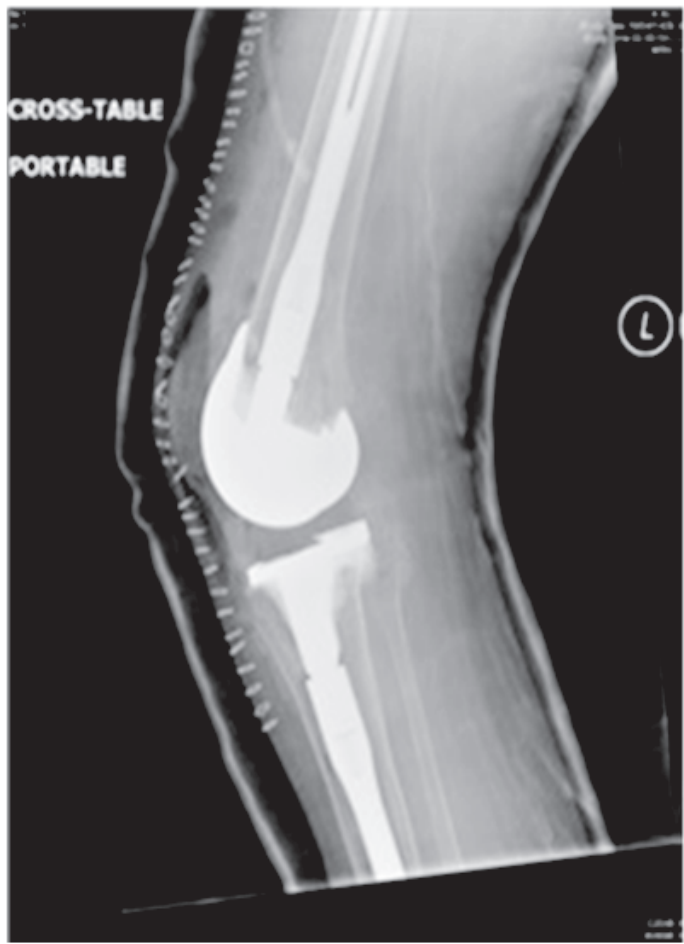

femur and atrophied; therefore, V-Y quadricepsplasty was done. Soft tissue was mobilized carefully around the joint prior to component insertion. Intraoperatively, knee flexion approached $50^{\circ}$. Post-left-TKR rehabilitation was severely restricted secondary to poor bone quality. This prevented adequate ROM exercises and function, and ROM gains at the knee were minimal. Poor bone quality also limited the ability for the patient to progress to functional lower extremity weight-bearing activities. Postoperatively, rehabilitation, patient education, transfer training and functional rehabilitation were carried out. This allowed the patient to transfer safely and independently from bed to wheel chair without much pain, and improved the quality of life by changing the patient's functional ability and allowing the freedom to mobilize independently with a wheelchair.

\section{Discussion}

Unlike normal red blood cells (RBC), sickled cells, due to abnormal morphology, are unable to negotiate small blood vessels resulting in arterial occlusion and subsequent ischemia. This process can ultimately damage tissues and vital organs. The prevalence of avascular necrosis (AVN) in sickle-cell-disease patients is increasing, especially with the increased life expectancy in these patients. It is believed that the AVN results from repeated episodes of localized areas of epiphyseal, metaphyseal and diaphyseal bone marrow infarctions, resulting in ingrowths of new bone as well as diffuse sclerosis resulting from vascular occlusion by sludging of sickle cells in the sinusoids. In general, the bilateral simultaneous THR

b.

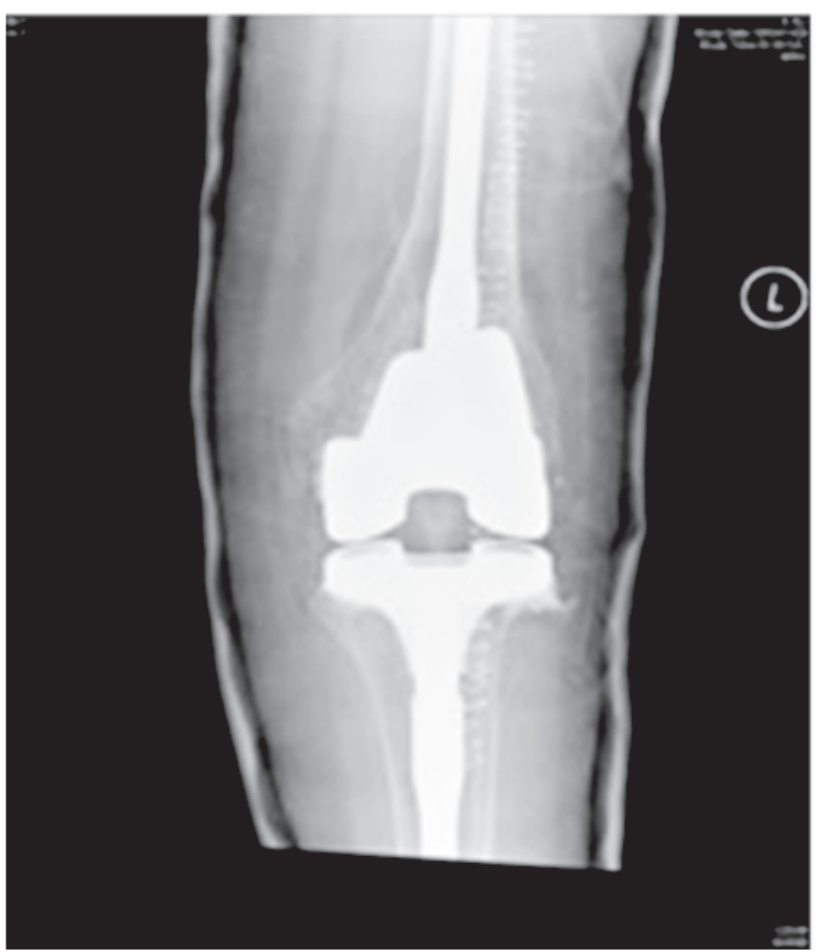

Figure 4. X-ray of left knee post TKR. 
has demonstrated better functional outcome than the staged procedure in patients with the same condition, with no significant increase in the rate of dislocation or thromboembolic events ${ }^{6}$. A similar case was published in 2000: a Congolese sickle cell patient was referred to Belgium for management of severe stiffness of all his major joints. That patient was managed by bilateral staged girdle stone procedure initially, with a subsequent surgical site infection of the left hip. The infection was managed with appropriate antibiotics and debridement. Once the infection was treated, the patient had a staged bilateral THR procedure. The patient regained his ability to walk with crutches after the surgeries ${ }^{4}$. Another case was reported in 2008: a 25-year-old female with severe ankylosis of her hips and knees secondary to rheumatoid arthritis, and her function was severely limited. She underwent staged bilateral THR, followed by a staged bilateral TKR, the functional outcome was excellent in that case as well ${ }^{7}$.

The increased life expectancy that medical advances have offered to the sickle-cell patients has led to the appearance of sickle-cell-related complications, which were previously only seen rarely. Orthopedic surgeons should be aware of the optimal management options as well as possible operative and postoperative complications of patients with this disease.

\section{Consent}

Written consent was obtained from the patient and the next of kin for the publication of the clinical details and clinical images related to the case report.

\section{Author contributions}

Both the authors have contributed equally for the study, the corresponding author wrote the manuscript.

\section{Competing interests}

No competing interests were disclosed.

\section{Grant information}

The author(s) declared that no grants were involved in supporting this work.

\section{Acknowledgements}

The authors are thankful to the orthopedic team at the Prince Sultan Medical Military City, asnd especially thank Dr. Abdularahman Al Asmari and Dr. Mohammed Arshaduddin for their help.
1. Modell B, Darlison M: Global epidemiology of haemoglobin disorders and derived service indicators. Bull World Health Organ. 2008; 86(6): 480-7. PubMed Abstract | Publisher Full Text | Free Full Text

2. Hammer M, Geuer KA, Aksoy S, et al.: Perioperative care for patients with sickle cell who are undergoing total hip replacement as treatment for osteonecrosis. Orthop Nurs. 2003; 22(6): 384-97. PubMed Abstract

3. Sadat-Ali M, Geeranvar SS, As-Suhaimi S, et al:: Orthopaedic complications in sickle cell disease. A comparative study from two regions in Saudi Arabia. Int Orthop. 1992; 16(3): 307-10. PubMed Abstract

4. Dumarey $\mathrm{N}$, Martin $\mathrm{P}$, Jayankura $\mathrm{M}$, et al:: A 'made in one piece' skeleton in a 22-years-old man suffering from sickle cell anaemia. Clin Rheumatol.
2000; 19(4): 287-90.

PubMed Abstract | Publisher Full Text

5. Firth PG, Head CA: Sickle cell disease and anesthesia. Anesthesiology. 2004; 101(3): 766-85.

PubMed Abstract

6. Tsiridis E, Pavlou G, Charity J, et al.: The safety and efficacy of bilateral simultaneous total hip replacement. An analysis of 2063 cases. J Bone Joint Surg Br. 2008; 90(8): 1005-12. PubMed Abstract | Publisher Full Text

7. Karva AR, Board TN, Porter ML, et al.: Conversion of bilateral hip and knee ankylosis to total joint replacements. $J$ Bone Joint Surg $B r$. 2008; 90(5): 668-73.

PubMed Abstract | Publisher Full Text 


\section{Open Peer Review}

\section{Current Peer Review Status:}

\section{Version 1}

Reviewer Report 29 November 2012

https://doi.org/10.5256/f1000research.204.r322

(C) 2012 Inati A. This is an open access peer review report distributed under the terms of the Creative Commons Attribution License, which permits unrestricted use, distribution, and reproduction in any medium, provided the original work is properly cited.

\section{Adlette Inati}

Division of Pediatric Hematology and Oncology, Children's Center for Cancer and Blood Diseases, Rafik Hariri University Hospital, Beirut, Lebanon

Avascular bone necrosis is a debilitating complication of sickle cell disease (SCD). Due to the prolonged life expectancy of SCD patients, the incidence of this complication is surging as it could be a manifestation of the disease chronicity.

In this case report, The authors present a severe case of ankylosis of hips and knees secondary to SCD. Indeed, the severity of this presentation is unusual and may be partially due to lack of prevention and optimal early management. Although the clinical management of the patient was not discussed, it would be interesting to know if this patient was on hydroxyurea or on antithrombotic agents and if he was enrolled in a comprehensive SCD care facility. Moreover, since the patient has been bedridden for eight years, it is possible that thrombophilic factors may have further exacerbated the condition and its progression to multiple joints.

Competing Interests: No competing interests were disclosed.

I confirm that I have read this submission and believe that I have an appropriate level of expertise to confirm that it is of an acceptable scientific standard.

Reviewer Report 25 October 2012

https://doi.org/10.5256/f1000research.204.r320

(C) 2012 Brandi M. This is an open access peer review report distributed under the terms of the Creative Commons Attribution License, which permits unrestricted use, distribution, and reproduction in any medium, provided the original work is properly cited.

\section{Maria Luisa Brandi}


Department of Internal Medicine, University of Florence, Viale Morgagni, Florence, Italy

This case report represents some very nice work.

Competing Interests: No competing interests were disclosed.

I confirm that I have read this submission and believe that I have an appropriate level of expertise to confirm that it is of an acceptable scientific standard.

The benefits of publishing with F1000Research:

- Your article is published within days, with no editorial bias

- You can publish traditional articles, null/negative results, case reports, data notes and more

- The peer review process is transparent and collaborative

- Your article is indexed in PubMed after passing peer review

- Dedicated customer support at every stage

For pre-submission enquiries, contact research@f1000.com 